\title{
Reviews
}

\section{Up Smith Creek}

\author{
George Smith
}

The White Lion Press Ltd, London, 2011; £12.95, 300pp.

ISBN: 978-0-9553993-4-3 (paperback)

Journal of Direct, Data and Digital Marketing Practice (2012) 13, 277-278. doi:10.1057/dddmp.2011.45

\section{Girls, brassières, and Ken Livingstone}

Witty.........

...and perceptive
What can you say about a man who writes an article about T-shirts, claiming to have played at Glastonbury with a band called Girls wear Brassieres, later renamed the Four Skins, featuring Ken Livingstone on keyboards?

Very few people write well. Even fewer are able to write well about our business. George Smith is a scintillating exception, because he writes about a great deal more than our business.

Not only does this book offer something to think about with a smile or two on every page, but if you know anyone interested in direct marketing — or any kind of marketing — it makes the perfect, thoughtful Christmas gift.

There are at least five excellent reasons why.

First, it is written with such a wit and lightness of touch that not a page is boring. The man has a style all his own; and I cannot tell you how hard it is to be different, let alone better.

Secondly, it is extraordinarily perceptive and funny about our business. The writer's explanation as to why clients should be forced to present themselves to possible agencies in a suitably grovelling fashion is only one of many pleasures it gave me.

Thirdly, George Smith, besides a sardonic but genial wit, has an extraordinarily good understanding of what this business is, or should be, about — and he feels strongly about what is right and wrong.

Fourthly, (and I know this having tried myself) being able to write consistently, week after week, year after year, about a pretty narrow subject in an entertaining and involving way is extraordinarily hard.

And fifthly, to be able to write about matters long past so well as to make them both relevant and engrossing today is almost impossible. I take my hat off to the man.

All this sounds so flattering that it makes me sound like George Smith's literary agent. Curiously enough, though, despite working in the same business for four decades, I hardly know George. I have missed a lot.

It is his flights of fancy that are especially pleasing. One piece that gave me a good laugh starts with the idea that there should be a 


\section{Well written}

checkout in his agency's reception to which clients would bring their completed creative work in a trolley, where the cost would be racked up on a big till by a junior member of staff.

'A mailing, two revised adverts, three media schedules and a concept .... Brenda, aren't we doing a special offer on concepts this month?'

See what I mean? There is hardly a page in this book - I would almost say not a paragraph - without its pleasures. And, as with all good writers, you can almost hear the man talking. I can only adapt some of what I wrote when first asked by the publisher to comment:

George Smith has rare wit; he writes extremely well. He makes the rest of us feel our living has not been made in vain. What he has written made sense when he wrote it, makes sense now and will make sense 50 years from now.

It really is true. Get the book. 